\title{
Manajemen Kelas dengan Pendekatan Savi dan Model Examples Non Examples
}

\author{
Agus Miftakus Surur \\ IAIN Kediri, Kediri, Indonesia \\ surur.math@gmail.com
}

\begin{abstract}
This research is a classroom action research. The use of the Examples non-examples type learning model with the SAVI approach is proven to be able to increase student learning activities in Islamic Religious Education lessons. From the results of the evaluation, it was explained that students reached $77 \%$ able to master the material, so that the learning carried out by the teacher could change the passivity of students before the application of learning methods, to become more active in learning, followed by an increase in the value of student learning outcomes.
\end{abstract}

Keywords: Management; Savi; Model Examples Non Examples

\begin{abstract}
Abstrak
Penelitian ini bertujuan untuk mengaktifkan siswa ketika belajar di kelas. Siswa tidak hanya diam saja, akan tetapi guru juga mendapat respon dari materi yang telah disampaikannya. Respon siswa tidak hanya berasal dari siswa tertentu, akan tetapi dapat menyeluruh dalam kelas. Pembelajaran yang dilakukan oleh siswa dengan memanfaatkan seluruh panca indera sangat ditekankan dalam pembelajaran SAVI ini. Penelitian Tindakan Kelas dipilih sebagai pendekatan yang digunakan dalam penelitian ini. Pembelajaran dalam materi Pendidikan agama islam terbukti dengan pendekatan SAVI dengan model pembelajaran tipe Examples Non examples mampu meningkatkan aktivitas belajar siswa. Dari hasil evaluasi menjelaskan bahwa peserta didik mencapai $77 \%$ mampu menguasai materi, sehingga guru yang melakukan pembelajaran dapat mengubah pasifnya siswa sebelum penerapan metode pembelajaran, menjadi lebih aktif dalam belajar, diikuti dengan meningkatnya nilai hasil belajar siswa.
\end{abstract}

Kata kunci: Manajemen; Savi; Model Examples Non Examples 


\section{A. Pendahuluan}

Salah satu aktivitas sadar adalah belajar yang dilakukan untuk menyiapkan bahan yang dibutuhkan dan memperoleh kesan yang disampaikan (Surur 2017b). Sebagai sasaran utama seorang individu dalam belajar adalah terjadinya perubahan yang signifikan. Guru dapat menggunakan strategi mengajar yang tersedia beragam untuk meningkatkan intensitas belajar siswa secara tepat dalam mengolah materi. Guru memilih strategi pembelajaran sesuai dengan tujuan pembelajaran supaya siswa senang dalam mengikuti pembelajaran yang disesuaikan dengan kemampuan siswa, sehingga siswa lebih aktif dalam belajar (Surur and Cholifah 2018). Dalam era modern ini penggunakan metode ceramah masih mendominasi pembelajaran yang sering dilakukan oleh guru. Selain itu juga terdapat kegiatan diskusi dan tanya jawab. Padaha IT sudah sangat maju dan banyak media yang dapat dimanfaatkan.

Penyiapan kemampuan peserta didik tentang menghayati, memahami, menyiapkan, mengenal dan mengimani, hingga sampai bertaqwa dan berakhlaq mulia ketika sumber utama hukum islam yang terdapat pada Al-qur'an dan Hadits diamalkan dalam ajaran agama Islam, diakhiri dengan latihan serta penggunaan pengalaman merupakan peran Pendidikan agama islam (Tim Pengembang Imu pendidikan FIP-UPI 2009). Kesadaran dibangun melalui peningkatan pemahaman mengenai ilmu-ilmu tentang ke-islaman, sehingga dalam praktiknya tidak terdapat keraguan karena pondasi keilmuan (Surur and Rahmawati 2018). Perencanaan berhubungan dengan pengamalan ilmu yang telah diperoleh, diawali dengan percobaan penerapan ilmu-ilmu tersebut dalam lingkungan sekolah yang dibimbing oleh guru yang berkompeten (Muslih 2016).

Pendidikan Agama Islam salah satu mata pelajaran di SMP yang sekarang mayoritas sudah menerapkan kurikulum 13 dengan seluruh kecanggihan dan kelengkapan sarana dan prasarananya. Kelengkapan dan kecanggihan sarana dan prasarana tidak serta merta meningkatkan kualitas pembelajaran (Surur, Habib, and Rais 2017). Hubungan tersebut seharusnya menghasilkan hubungan timbal-balik yang saling mendukung. Akan tetapi pengelolaan yang kurang baik akan hal tersebut, maka hanya akan sebagai pajangan yang tidak berpengaruh dalam pembelajaran. Berkaitan dengan hal tersebut munculah permasalahan pada mata pelajaran Pendidikan Agama Islam dimana aktivitas belajar siswa yang monoton dan guru masih menggunakan model pembelajaran lama seperti menggunakan metode ceramah.

Dari hasil pengamatan yang dilakukan peneliti dihadapkan dengan situasi yang menarik untuk diselesaikan, karena siswa diam mendengarkan guru Ketika menjelaskan materi. Sesekali siswa yang sering menjawab di kelas memberikan tanggapan yang diberikan oleh guru. Kondisi seperti ini berakibat ketika mengerjakan Latihan soal, 
siswa mengalami kebingungan untuk menjawab soal. Ada yang terlihat menengok ke kanan dan ke kiri. Ada yang sambal jalan, dan ada juga menjawab sebisanya, walaupun juga ternyata jawabanya masih banyak yang kosong.

Selain itu waktu pengumpulan tugas yang seharusnya pukul 11.30 yang menjadi waktu istirahat sebelum melakukan sholat dhuhur berjamaah, menjadi hingga hamper pukul 12.00. akibatnya para siswa tidak dapat waktu untuk istirahat, walaupun ketika sholat dhuhur berjamaan tidak tertinggal.

Dengan adanya masalah tersebut tentunya juga ada solusinya, salah satu metode yang dirasa mampu meningkatkan aktivitas belajar siswa untuk mendapatkan hasil yang optimal, yaitu dengan proses yang menyenangkan dengan model pembelajaran examples non examples melalui pendekatan SAVI (somatic, auditory, visual dan intelectual). Pembelajaran SAVI memberikan penekanan pada pemanfaat keseluruhan indera yang dimilki siswasehingga terjadi pengalaman yang lebih pada pengetahuan siswa (Susilo 2006).

Pembelajaran Examples Non examples (model pembelajaran didalmnya terdapat contoh dan bukan contoh) merupakan salah satu pembelajaran system kelompok. Kelompok yang dibentuk diupayakan heterogen (kemampuan siswa merata). Sajian pembelajaran dapat berupa tabel, diagram atau gambar disesuaikan dengan materi kompetensi dasar dan bahan ajar yang tersedia. Penggunaan contoh dan bukan contoh menjadi ciri khas dari pembelajaran Examples Non examples. Salah satu kelebihan dari pembelajaran Examples Non examples adalah mampu berpikir kritis siswa dapat ditingkatkan dalam menganalisa media yang diberikan. Siswa juga dapat mengaplikasikan materi serta siswa diberi kesempatan yang luas dalam menyampaikan argumen (Yensi 2012).

Berdasarkan penelitian terdahulu, Metode Examples Non Examples dan pendekatan SAVI terbukti efektif dalam membangkitkan semangat belajar siswa. Hasil aktivitas belajar siswa meningkat karena aktivits yang dilakukan di kelas meliputi presentasi dan diskusi kelompok, penjelasan, penyimpulan materi serta evaluasi yang dilakukan guru yang dilakukan kolompok siswa yang heterogen (Yensi 2012). Belajar secara individu atau dengan kelompok dengan model ini mampu meningkatkan antusias peserta didik dalam belajar. Penerapan model pembelajaran Kooperatif Tipe Examples Non Examples persamaan dengan penelitian tersebut adalah dalam hal dan juga dalam segi hasil pembelajaran, menjadikan siswa menjadi lebih meningkat kemampuan yang ditentukan peneliti. Perbedaannya terletak pada pendukung. Pada penelitian ini tidak memerlukan alat peraga, sehingga lebih mudah dalam penerapan di kelas, hanya 
diperlukan kreativitas seorang guru dalam mengkolaborasikan SAVI dengan model pembelajaran yang dipilih.

Peningkatan keaktifan ditunjukkan dengan proses keikutsertaan proses belajar mengajar dengan pendekatan SAVI dari tahap pra siklus ketahap siklus I dan siklus II (Mashudi 2017). Model ini membutuhkan penguasaan teori sekaligus prakteknya sebelum diimplementasikan kepada peserta didik. Perbedaan dengan penelitian ini adalah penggunaan model pembelajarannya yang lebih umum digunakan dalam pembelajaran, yaitu pembelajaran kelompok. Jika dalam kajian penelitian ini menggunakan sosiodrama yang membutuhkan banyak energy dan ruang sehingga membutuhkan energi yang ekstra, dalam penelitian ini akan lebih memudahkan guru dalam penerapan di kelas.

Selain itu, hasil penelitian dari Masnah mengalami peningkatan dalam kemampuan melaksanakan shalat sunnat rawatib dan menghafal bacaan dalam sholat dengan menerapkan SAVI pada siswa SMP N 1 Banjar Margo. Siswa kelas VIII menunjukkan hasil yang meningkat pada kemampuan menghafal bacaan-bacaan shalat sunnat rawatib, lebih baik ketika telah menerapkan pendekatan SAVI (Masnah 2018). Penelitian yang lain yaitu dari Amrianto dan Lufri mengatakan bahwa Metode ini memenuhi tiga pola pembelajaran yang disyaratkan oleh Kurikulum 2013. Pengaruh metode example non example ingin diketahui dalam penelitian tersebut. Terdapat pengaruh metode example non example terhadap kompetensi kognitif siswa dari hasil data penelitian (Amrianto and Lufri 2019). Kedua penelitian tersebut memiliki kesaman dalam hal pembelajaran dengan pendekatan SAVI. Poin lebih pada penelitian ini adalah, mengasah kemampuan siswa dalam berpendapat tentang materi yang dibahas sehingga tidak sekedar menghafal saja, tapi juga paham, dan itu karena usaha guru dalam pembelajaran menggunakan metode example non example sehingga memberikan pengaruh positif secara langsung terhadap kemampuan siswa.

Adapun rumusan hipotesis yang ditawarkan adalah peggunaan model pembelajaran tipe Examples Non Examples pada pelajaran Pendidikan Agama Islam dengan pendekatan SAVI dapat dibuktikan dengan adanya peningkatan aktivitas belajar siswa. Penelitian ini menggunakan model Action Research Kurt Lewin (Ahmad 2009) terdapat empat komponen utama, diawali dengan perencanaan (planning). Langkah berikutnya adalah tindakan (acting) bersamaan dengan proses pengamatan (observing), dan terakhir adalah refleksi (reflecting). Model ini dipilih karena bersifat luwes atau fleksibel, sehingga dapat dikembangkan selama penelitian berlangsung (Pujiono 2008). 


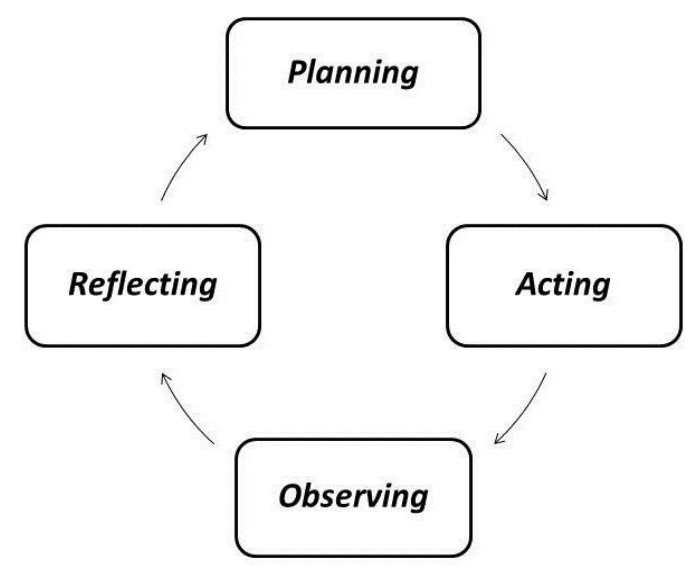

Gambar 1: Model Kurt Lewin

(diadaptasi dari Depdiknas, 2005)

Cara yang digunakan untuk memperoleh data diantaranya adalah: (1) Observasi aktivitas guru dan siswa, dilaksanakan peneliti dan kolaborator selama KBM berlangsung. Selama pembelajaran aktivitas guru dan siswa direkam dalam beberapa bentuk, diantaranya disesuaikan dengan lembar observasi yang telah dibuat, menggunakan catatan lapangan dan juga perekaman dengan menggunakan media/alat; (2) Penilaian (Assesment), diambil dari hasil pretes dan postes. Pretes dan postes berupa pertanyaan yang akan diajawab oleh siswa mengenai materi yang akan diajarkan. Ini juga sebagai langkah awal dalam melihat kemampuan siswa dan efek pembelajaran siswa mengenai pembelajaran yang diterapkan oleh guru; (3) wawancara, untuk menggali respon siswa selama pembelajaran berlangsung, segala kegiatan siswa dan guru selama KBM berlangsung dan juga materi yang disampaikan oleh guru tentang kesulitan dan kemudahannya.

Analisis aktivitas guru dan murid dari data hasil observasi, penilaian, serta catatan lapangan dari seluruh data yang diperoleh perlakuan dengan tujuan untuk menarik kesimpulan (Fitrah and Luthfiyah 2018). Data berupa catatan lapangan, hasil observasi aktivitas guru dan siswa dianalisis dengan teknik analisis deskriptif dalam bentuk penarikan kesimpulan (Surur 2017a). Sedangkan data observasi dan assesment dapat dianalisis dengan angka-angka.

Kriteria keberhasilan tindakan perbaikan ditetapkan secara eksplisit, sehingga membantu dalam mengkategorikan dan verifikasi hasil analisis aktivitas siswa dalam meningkatkan keaktifan berpikir kritis (Surur 2019). Nilai 70 diambil sebagai nilai supaya masuk dalam kriteria ketuntasan belajar siswa. Apabila terdapat $70 \%$ siswa yang telah mencapai 70 ketuntasan belajar individu sebagai kriteria ketuntasan belajar klasikal. Hal ini ditetapkan $(70 \%)$ karena di awal pembelajaran siswa yang tuntas 
belajar (nilai di atas KKM) sebesar 56\%, sehingga peneliti menetapkan $70 \%$ sebagai batas minimal keberhasilan dalm penelitian ini, artinya missal dalam kelas ada 100 siswa, awal sebelum pembelajaran hanya 56 siswa yang nilainya di atas KKM, maka setelah tindakan diharapkan minimal 70 siswa memperoleh nilai di atas KKM.

\section{B. Pembahasan}

\section{Pendekatan SAVI pada Pembelajaran PAI}

Salah satu dari beberapa mata pelajaran wajib yang harus dipelajari pada dunia Pendidikan adalam pelajaran PAI, khususnya pada jenjang sekolah, peserta didik menyerap dan memahami materi yang telah disampaikan oleh guru berbenuk suatu motivasi yang tinggi dalam belajar, serta peserta didik merasakan kenamanan dalam belajar, maka sangat diperlukan penggunaan pendekatan, metode serta media pembelajaran untuk membantu fleksibelnya guru ini. Belajar secara kelompok, menggunakan pendekatan saintifik dan didalamnya diselingi dengan humor akan dapat menjadikan pembelajaran menyenangkan (Widodo 2016).

Kenyataan dilapangan berkata lain, peserta didik memandang rendah pelajaran PAI yang disampaikan oleh guru. Guru menggunakan metode ceramah dilanjutkan dengan Latihan-latihan soal, walaupun sebenarnya materi yang dipelajari memungkinkan untuk praktik (Wawancara dengan guru pada kegiatan observasi awal). Ada diantara mereka beralasan karena PAI dianggap mudah, metode pembelajaran yang monoton tidak akan memberikan rangsangan kepada peserta didik untuk bersemangat. Beberapa hal yang menyebabkan pembelajaran tidak menyenangkan yaitu siswa merasa takut dalam mengikuti pembelajaran, tidak dapat berekspresi sesuai kehendak siswa, perasaan terancam, pengajar terlalu otoriter, tidak ada motivasi dalam belajar, tidak berminat, ingin jam belajar segera usai, pembelajaran tidak berganti, pembelajaran tidak menjadi focus siswa (Wijanarko 2017). Kemudahan dirasa dari sisi penerapan yang sudah terbiasa dilakukan oleh guru dan siswa, sahingga untuk pemahaman mengenai materi yang berkaitan tidak cukup respon yang mampu menanamkan pemahaman dalm siswa. Hal ini juga pengaruh dari kemampuan guru yang sudah sering menyampaikan materi karena setiap tahun pasti diajarkan, sehingga mencari pembelajaran yang sudah biasa dilakukan setiap tahunnya.

Pendekaan SAVI fokus pada potensi-potensi yang dimiliki oleh peserta didik yang mampu menjadikan pembelajaran menjadi efektif. Fokus terhadap pembelajaran yang efektif menjadikan peserta didik lebih fokus. Semua ketrampilan yang ada pada diri peserta didik dimaksimalkan. Penerapan pendekatan pembelajaran ini sebagai sarana untuk meningkatkan antusias siswa dalam mengikuti pembelajaran sehingga 
memberikan efek kebaruan dalam pembelajaran. Selain itu juga sebagai tahapan kemampuan-kempuan yang ingin dilakukan. Mempunyai variasi dalam pembelajaran yang nantinya membuat siswa penasaran dalam mengikuti pembelajaran.

Pembelajaran berlangsung pada banyak tingkatan mengandung emosi positif, secara simultan yang menjadikan pembelajaran menjadi terbantu, informasi diserap oleh otak secara langsung dan dan menimbulkan citra secara otomatis. Pendekatan SAVI terdapat prinsip yang menjadi pokok dalam belajar. Belajar melibatkan seluruh tubuh dan pikiran, pengerjaan pekerjaan menjadi proses belajar itu sendiri, berkreasi bagian dari belajar, tidak hanya menerima jadi, akan tetapi terdapat kerja sama menjadikan pembelajaran lebih berarti (Mariati and Ningsih 2016).

Pembelajaran di kelas, tidka terkecuali pembelajaran PAI masih menekankan pada satu aspek saja. Aspek tersebut adalah aspek kognitif. Padahal, secara materi yang dipelajari nantinya akan diamalkan dalam keseharian, sehingga ada baiknya pengetahuan kognitif tersebut ditekankan untuk merasuk pada jiwa peserta didik. Peserta didik menjadi tidak focus karena tidak diberikan kesempatan untuk dalam terlibat langsung dalam proses sains dan pembelajaran masih berpusat pada guru (Maulidiah, Fadillah, and Yuniarni 2016). Hal ini terlihat ketika proses pembelajaran berlangsung yang didominasi oleh guru dan siswa diberikan kesempatan untuk mengerjakan Latihan soal setelah penjelasan dari guru, sehingga siswa tidak sampai memperagakan materi yang sedang dipelajari.

Hal tersebut terjadi dengan alasan guru bahwa yang dipelajari siswa itu sulit maka pembelajaran dilakukan semudah mungkin sehingga mereka dapat meyelesaikan waktu tepat waktu. Selain itu juga kesibukan tugas guru selain mengajar juga menjadi penghambat. Hal ini membuat guru tidak mampu membuat inovasi pembelajaran seperti yang diinginkan oleh siswa.

Demi terwujudnya pembelajaran yang inovatif, diprlukan pembelajaran PAI dengan pendekatan khusus. Sisi pengamalan disini yang dapat membuat siswa merasa bosan dan tidak antusias, dari sisi ini juga guru memulai pembelajaran disesuaikan dengan kemampuan awal siswa. Pembelajaran mengarah pada materi (konsep-konsep) yang sesuai dengan kegiatan-kegiatan yang sudah biasa dilakukan oleh siswa, sehingga siswa mengetahui dasar hukum dalam setiap pengamalannya.

Sebelum melakukan penelitian, peneliti mempersiapkan hal-hal yang dibutuhkan saat penelitian. Diawali dengan meminta persetujuan Kepala Sekolah untuk mengadakan penelitian. Kunjungan ke sekolah dilakukan untuk melihat secara langsung cara pembelajaran di kelas yang dilakukan oleh guru, baik dari aktivitas guru maupun siswanya. Dilanjutkan dengan penentuan topik permasalahan yang akan diteliti 
berdasarkan keresahan akademik yang terjadi. Keresahan diperoleh dari hasil diskusi dengan guru pengampu yang sudah mengetahui karakter dari siswa. Metode yang sesuai atau Langkah-langkah yang tepat perlu ditekankan berdasarkan keresahan dan demi mengatasi keresahan yang dialami oleh guru.

Berangkat dari topik permasalahan di lokasi yaitu situasi yang menarik untuk diselesaikan, karena siswa diam mendengarkan guru ketika menjelaskan materi., selanjutnya objek penelitian yang dipilih oleh peneliti (kelas VII) dipilih berdasarkan rekomendasi dan pertimbangan dari guru Pendidikan Agama Islam di kelas VII. Tahap berikutnya yang harus dilakukan peneliti adalah merencanakan langkah-langkah tindakan pelaksanaan pembelajaran yang akan dilakukan dalam penelitian. Dan terakhir peneliti memepersiapkan metode yang akan diimplementasikan, serta menyusun soal evaluasi (lembar kerja siswa) beserta kunci jawabannya.

Penelitian ini diawali dari hasil kegiatan observasi yang sebelumnya sudah dilakukan oleh peneliti dan refleksi menjadi lanjutan dari kegiatan tersebut. Hasil tersebut menunjukkan bahwa, peran guru lebih dominan atau lebih aktif sebagai penyampai informasi pada peserta didik dalam kegiatan pembelajaran. Peran guru lebih dominan karena materi hanya bersumber dari guru, sehingga kelas menjadi pasif dengan dominannya guru dalam menyampaikan materi (Wawancara dnegan guru mata pelajaran).

\section{Metode Pembelajaran Examples non Examples dengan Pendekatan SAVI}

Berdasarkan pengamatan awal menunjukkan bahwa minat siswa dalam kegiatan pembelajaran Pendidikan Agama Islam dinilai kurang dibandingkan dengan mata pelajaran lain (Hasil observasi aktivitas mahasiswa sebelum penelitian). Mata pelajaran lain yang dimaksud adalah mata pelajaran yang juga menerapkan praktik dalam pembelajaran. Materi tersebut dapat dilakukan seimbang antara teori dan praktik, karena materi baru dan praktik juga tidak dilakukan dalam keseharian siswa, sehingga siswa aktif dalam pembelajaran. Mata pelajaran PAI karena sudah terbiasa mempraktikkan, sehingga dalam penyampaian materi kurang terasa diminati oleh siswa. Keaktifan guru dalam menyampaikan materi tidak diimbangi dengan aktifnya peserta didik, akibatnya peserta didik menjadi pasif dan kurang tanggap terhadap materi yang disampaikan oleh guru.

Metode ceramah masih menjadi tren pembelajaran yang digunakan oleh guru ketika pembelajaran, bahkan dilakukan dari awal sampai akhir pembelajaran, sehingga dari hasil pengamatan yang peneliti lihat memperlihatkan guru lebih dominan dalam pembelajaran dan kondisi peserta didik yang cenderung bosan dan kurang aktif (hasil observasi ketika pembelajaran berlangsung). Hal ini ditunjukkan keaktifan hanya pada 
siswa yang ditunjuk oleh guru dan tidak dari dalam diri siswa sendiri, kebosanan terlihat dengan adanya siswa yang berbicara dengan teman sebangkunya, menggambar dibuku tulis dan ada yang meletakkan kepala di atas bangku. Beberapa hal tersebut yang menjadi dasar dalam penerapan suatu metode pembelajaran di kelas tersebut.

\section{Implementasi Metode Pembelajaran Examples non Examples dengan Pendekatan SAVI}

Peningkatan keaktifan peserta didik dengan menerapkan metode pembelajaran Examples non Examples dengan pendekatan SAVI dalam pembelajaran di kelas. Hal ini terlihat dari antusias siswa untuk mengikuti instruksi yang diberikan oleh guru, dan juga beberapa siswa secara respon langsung bertindak walaupun ternyata aktifitasnya tidak sesuai intruksi. Hal ini menjadi nilai tambah karena siswa mulai diberi kepercayaan dalam keaktifan ketika pembelajaran di kelas (hasil penelitian pertemuan pertama). Diawali dengan pembukaan pembelajaran guna mempersiapkan siswa dalam menggali pengetahuan. Dilanjutkan dengan penyampaian materi ketika proses pembelajaran menggunakan metode Examples non Examples dengan pendekatan SAVI. Diskusi kelompok dan persentasi kelompok dari hasil diskusinya secara bergantian tetap dilakukan di kelas ketika pembelajaran metode ini.

Implementasi penerapan metode pembelajaran Examples non Examples dengan pendekatan SAVI, mampu membuat aktivitas yang dilakukan siswa sesuai dengan yang sudah dirancang dan tertuang dalam RPP. Aktivitas yang terlihat yaitu:

a) Perencanaan Penelitian

Peneliti menyiapkan beberapa hal untuk keperluan pembelajaran dan penilaian. Di awali dengan membuat atau menyalin daftar nama peserta didik dari data base yang dimiliki oleh guru. Kemudian menyiapkan RPP yang disesuaikan dengan materi yang akan dipelajari. Materi yang disampaikan dibagi menjadi dua bagian karena ada materi yang disampaikan dan ada materi yang digunakan untuk diskusi kelas. Untuk kepentingan aktifitas, peneliti Menyusun lembar observasi aktivitas guru dan siswa. Dan terakhir meyiapkan lembar soal sebagai pengukur hasil pembelajaran.

b) Pelaksanaan Tindakan

Ketika semua instrument sudah siap untuk digunakan dan waktu sudah menunjukkan jadwal untuk memulai penelitian, maka peneliti memulai penelitian sesuai dengan jadwal. Kegiatan yang dilakukan pada penerapan model pembelajaran Examples non Examples dengan pendekatan SAVI. Pertemuan ini menyampaikan materi pokok Pentingnya Ilmu Pengetahuan menjadi pusat dalam pelaksanaan tindakan siklus I. menjawab salam menjadi aktivitas awal siswa dalam pembelajaran. Dilanjutkan guru 
melakukan apersepsi dengan menyampaikan garis besar materi, dan dilanjutkan dengan penyampaian materi sebagai pengantar pembelajaran. Selanjutnya peserta didik menjadi beberapa kelompok dengan beranggotakan 4 siswa yang dibentuk oleh guru untuk setiap kelompok.

Setelah itu, guru memberikan intruksi tentang yang harus dikerjakan oleh setiap kelompok. Guru memberikan waktu kepada siswa guna mendiskusikan tugas kelompok dengan durasi waktu 9 menit, dan setelah selesai berdiskusi, setiap kelompok mempresentasikan hasil diskusi. Ketika peserta didik mempresentasikan hasil tugas kelompoknya, guru menilai sikap peserta didik dan hasil diskusi. Penilaian sikap untuk data sebagai tentang aktifitas guru dan siswa, sedangkan hasil diskusi sebagai pengukur kemampuan siswa setelah pembelajaran.

Hasil diskusi peserta didik cukup memuaskan (penelitian siklus I). Sudah sesuai dengan target pembelajaran. Hal ini ditunjukkan dengan kegiatan yang dilakukan sebagian besar atau $80 \%$ lebih sudah sesuai dengan RPP yang telah disusun, juga aktifitas yang diinginkan guru kepada siswa juga terlaksana lebih dari $75 \%$.

Peningkatan aktifitas seperti ini tidak serta-merta terlaksana adalam satu kali pertemuan (penelitian siklus I). Bertahap mulai dari keterlaksanaan 50\%. Kemudian dilakukan refleksi dari bagian yang diperlukan, seperti teknik pencingan atau tugas kepada siswa lebih diposisikan terhadap siswa. Guru mengurangi penjelasan supaya siswa alebih aktif dalam kelas. Hal ini sebagai poin penting dalam refleksi untuk kemudian diterapkan dalam pembelajaran selanjutnya. Setelah selesai, guru menyimpulkan materi dan menutup pembelajaran dengan mengucap salam.Setelah pembelajaran selesai guru memberikan evaluasi soal-soal berupa essay. Peserta didik harus menjawab soal-soal dengan jelas dan tepat. Pemberian tes adalah dilakukan untuk mengetahui kemampuan akhir siswa setelah pembelajaran di kelas. Data ini yang akan digunakan dalam memonitoring tingkat keberhasilan setelah dilakukan pembelajaran ini.

\section{c) Pengamatan}

Peserta didik diamati aktivitasnya ketika pembelajaran. Pengamatan yang dilakukan peneliti yaitu aktivitas pembelajaran guru dan peserta didik dengan menggunakan metode pembelajaran Examples non Examples dengan pendekatan SAVI proses pengamatan dilakukan oleh guru dan juga dibantu oleh observer. Observer dipilih dari teman sejawat peneliti yang juga sedah melakukan penelitian. Guru sebagai observer karena untuk mengawasi secara langsung pembelajaran di kelas, guna untuk menambah pengetahuan guru mengenai model pembelajaran dan juga sebagai pemberi 
masukan kepada peneliti untuk menambahkan hal-hal yang dirasa diperlukan perbaikan (penelitian tanggal 30 November 2019).

Selama penyampaian materi, peserta didik menyimak dengan seksama tanpa ada yang bersuara. Namun ketika memasuki sesi berkelompok, terbentuk jalinan Interaksi antar peserta didik dalam dalam kelompoknya seperti saling menanggapi pendapat, saling bekerja sama, saling menjelaskan, saling membaca dan memahami. Pada tahap ini tingkat keaktifan peserta didik hampir sama, hanya saja ada beberapa peserta didik yang lebih pandai seolah berperan sebagai pemimpin dari kelompok tersebut.

Tindakan penelitian ini membantu guru dalam meningkatkan keaktifan semua peserta didik di dalam kelas. Dari yang semula hanya satu dua peserta didik yang aktif menjadi hampir semua peserta didik lebih aktif. Peran dari peserta didik yang pandai pun kini tidak hanya aktif untuk dirinya sendiri tetapi juga terhadap temannya dalam membantu memahamkan. Yang dilakukan guru adalah memberikan masukan kepada siswa yang aktif untuk diam sejenak mendengarkan teman/ anggota kelompok yang lain untuk berpendapat. Juga dapat menginteruksi supaya siswa yang sudah terbiasa berbicara didalam kelompok membisikkan suatu hal supaya teman yang awalnya diam menjadi ikut berbicara dari ide siswa yang aktif.

Kegiatan tersebut dapat membantu siswa dalam aktif di kelas. Keaktifan siswa di kelas disesuaikan dengan tujuan yang akan dicapai oleh peneliti. Mata pelajaran ini membutuhkan keaktifan siswa, sehingga keaktifan sebagai kunci dalam pembelajaran yang sedang dilakukan.

Bersamaan dengan pengamatan aktivitas siswa, kegiatan pembelajaran yang dikelola oleh guru turut diobservasi oleh peneliti yang dalam enerapannya guru menggunakan metode pembelajaran Examples non Examples dengan pendekatan SAVI, diperoleh hasil (1) Guru mampu menciptakan suasana pembelajaran yang aktif. Hal ini ditinjukkan dengan guru selalu menghampiri kelompok-kelompok diskusi yang dilakukan siswa. Mengamati siswa yang aktif dan pasif dalam kelompok. Serta memberikan masukan pada siswa yang aktif dalm kelompok. (2) Bimbingan kelompok. Bimbingan kinerja guru ketika berkelompok sekaligus dengan memberkan dorongan bekerjasama dan memecahkan masalah. Pemberian motivasi dilakukan oleh guru di awal kelas, supaya siswa nantinya dalam belajar dengan sungguh-sungguh, mengikuti semua kegiatan yang akan dilakuakn/diterapkan oleh guru, memberikan arahan pada kelompok mengenai tugas setiap kelompoknya, dan secara klasikal, guru memberikan contoh cara pengerjaan tugas setiap kelompoknya. (3) Guru terlalu larut dalam metode pembelajaran yang menyenangkan sehingga lupa menyampaikan beberapa poin penting dari materi. 
Hal ini terjadi karena metode yang dilakukan guru memang sangat dinikmati oleh siswa. Akan tetapi kesenangan ini menjadi boomerang pada guru yang akibatnya tidak sesuai dengan yang telah direncanakan. Hal ini terjadi di awal pembelajaran. Setelah memperoleh masukan-masukan dari observer, peneliti merefisi bagian-bagian yang kurang, sehingga di hari berikutnya pembelajaran semakin baik dan tepat sesuai dengan sasaran. Agar guru dapat terjadi pembelajaran yang baik sesuai dengan jam mengajar dan memantu kebutuhan materi yang harus tersampaikan dalam satu pertemuan.

Hasil pengamatan terhadap tindakan guru yang bersamaan dengan aktivitas pengamatan aktivitas siswa, menunjukkan kompetensi guru sangat baik. Hal ini terlaksana karena persiapan dan perencanaan yang matang sebelum pembelajaran, serta proses refleksi yang dilakukan guru setelah pembelajaran. Selain itu, aktivitas guru dari awal pembukaan hingga akhir penutupan menunjukkan perbuatan guru sesuai dengan aspek pengamatan. Aspek pengamatan mengacu pada kegiatan yang terdapat dalam rencana pembelajaran. Hal ini berdasarkan hasil dari lembar aktivitas guru dan siswa yang telah di isi oleh observer. Sedangkan hasil dari refleksi yang dilakukan guru dalam mengevaluasi seberapa jauh pemahaman peserta didik dinilai sudah berhasil, karena sebagian besar peserta didik mampu menjawab soal ulangan harian dengan jawaban yang tepat. Siswa yang menjawab tepat totalnya diatas kriteri yang telah ditentukan oleh peneliti.

\section{d) Hasil evaluasi pembelajaran}

Isi hampir sama dengan penjelasan di atas, yang juga menghubungkan dari hasil penelitian dihubungkan dengan rumus rencana pencapaian persentasi target guru yakni $70 \%$ sudah tercapai. Hal ini dilihat dari hasil evaluasi yang sudah dilakukan oleh guru. Dari hasil evaluasi menjelaskan bahwa peserta didik mencapai $77 \%$ mampu menguasai materi. Maka keberhasilan guru dalam pembelajaran telah tercapai.

Hasil pembelajaran juga dilihat dari hasil jawaban siswa setelah pembelajaran. Berikut adalah salah satu hasil jawaban pada saat pembelajaran. Dari jawaban di atas terlihat siswa mampu menjawab pertanyaan yang disampaikan oleh guru. Beberapa jawaban masih terlihat kurang tepat dengan pertanyaan yang disampaikan oleh guru, akan tetapi hal itu sebagai suatu kewajaran. Sebagai poin pentingnya adalah tentang nilai yang diperoleh siswa. Sesuai dengan harapan guru setelah pembelajaran. Guru juga melaksanakan tugasnya dengan baik, yaitu mengoreksi hasil siswa dengan detail. Ini ditunjukkan oleh guru memberikan nilai setengah pada jawaban yang dirasa kurang tepat dan memberikan tanda lingkaran pada jawaban yang kurang. Membantu siswa dalam membenarkan jawaban yang belum benar. 
e) Refleksi

Hasil observasi dan Tindakan di atas sebagai bahan untuk melakukan refleksi oleh guru dan peneliti untuk merancang pembelajaran berikutnya menjadi lebih baik. Hasil refleksi tersebut yaitu guru sudah menciptakan suasana yang menjadikan peserta didik aktif dan menyenangkan dalam suasana pembelajaran. Hal ini ditunjukkan dengan aktifitas guru dalam kategori penguasaan materi dan juga aktifitas siswa dalam kategori aktif. Hasil yang lain yaitu ketika evaluasi pembelajaran menunjukkan kategori berhasil hal ini ditunjukkan dengan hasil penelitian.

Menurut Gegne, Fase belajar yang dialami pembelajar perlu seorang tenaga pengajar menyelaraskan pengkondisian kelas ketika pembelajaran perlu dilakukan oleh pengajar. Hasil belajar dalam suatu pembelajaran dapat ditingkatkan dan dipertahankan demi meningkatkan kualitas belajar, sehingga suatu aktivitas (proses belajar) tiap fase belajar dapat menghasilkan sesuatu yang maksimal dalam diri siswa ketika mengikuti pembelajaran (Suyatno 2009).

Pada proses pembelajaran, sudah sejalan dengan Rencana Pelaksanaan Pembelajaran (RPP) langkah pembelajaran yang telah dirancang oleh peneliti diimplementasikan dan menggunakan pedoman Buku Paket Akidah Akhlak. Dalam pengimplementasian metode pembelajaran Examples non Examples dengan pendekatan SAVI dilakukan sesuai dengan rencana. Peneliti dapat mengimplementasikan metode ini sehingga peserta didik dengan antusias atau sangat aktif untuk mengikutinya. Dilanjutkan dengan pembagian kelompok, setiap kelompok terdiri dari 5 siswa, akan tetapi ada juga yang 6 siswa. Setiap kelompok bertugas untuk mendiskusikan hasil pembelajaran yang diperoleh dan guru meminta setiap kelompok mempresentasikan hasil diskusinya. Akhir dari sesi diskusi diadakan penguatan materi oleh guru. Kemudian setelah sesi diskusi selesai, selanjutnya guru meminta siswa untuk mengulang materi bersamaan dengan menggunakan metode Examples non Examples dengan pendekatan SAVI. Sebelum memasuki tahap selanjutnya, guru memberi icebreaking sekaligus punishment terhadap siswa yang ramai sendiri dalam bentuk pengulangan materi secara mandiri.

\section{Simpulan}

Penggunaan pendekatan SAVI mata pelajaran Pendidikan Agama Islam model pembelajaran tipe Examples Non Examples terbukti mampu aktivitas pembelajaran di kelas menjadi naik dan aktif ketika belajar. Dari hasil evaluasi menjelaskan bahwa peserta didik mencapai $77 \%$ mampu menguasai materi, sehingga keberhasilan guru dalam mengajar sudah tercapai sesuai kreteria awal. 
Rencana Pelaksanaan Pembelajaran (RPP) oleh peneliti diimplementasikan sudah sesuai dan menggunakan pedoman Buku Paket Akidah Akhlak. Penerapan pendekatan SAVI metode pembelajaran Examples non Examples keaktifan siswa dapat ditingkatkan pada pembelajaran yang dilakukan di kelas. Kegiatan pembelajaran pada kelas VII mata pelajaran Pendidikan Agama Islam menunjukkan hasil bahwa, peran guru lebih dominan atau lebih aktif sebagai penyampai informasi pada peserta didik.

\section{DAFTAR PUSTAKA}

Ahmad, Kasina. 2009. "Penelitian Tindakan Kelas.” Jurnal Pendidikan 8(1): 1-112.

Amrianto, A., and L. Lufri. 2019. "Effect of Example Non Example Method Implementation in Scientific Approach and Discovery Learning Model on VII Grade Students' Cognitive Competence in Learning Natural Science.” Journal of Physics: Conference Series 1387(1).

Fitrah, Muh., and Luthfiyah. 2018. Metodologi Penelitian: Penelitian Kualitatif, Tindakan Kelas \& Studi Kasus. Sukabumi: CV Jejak (Jejak Publisher).

Mariati, Siti, and Amalia Riyanti Ningsih. 2016. "Upaya Meningkatkan Kemampuan Mengahafal Hadist Dengan Model SAVI Pada Mata Pelajaran Al-Qur'an Hadits Kelas III Di MI Darun Najah Tulangan Sidoarjo." Penelitian Tindak Kelas Pendidikan Agama Islam 7(1): 78-80.

Mashudi, Imam. 2017. "Implementasi Metode Sosiodrama Pada Mata Pelajaran Pendidikan Agama Islam Materi Berempati Itu Mudah Menghormati Itu Indah Dengan Pendekatan SAVI Untuk Meningkatkan Hasil Belajar Siswa Kelas VII D Di SMPN 2 Tugu Trenggalek Tahun Pelajaran 2016-2017.” Tarbawi 1(1): 12.

Masnah. 2018. "Pendekatan Savi: Model Examples Non Examples Untuk Meningkatkan Aktivitas Dan Hasil Belajar Siswa Smpn 1 Banjar Margo Kabupaten Tulang Bawang." Dewantara 4(2).

Maulidiah, Dian, Fadillah, and Desni Yuniarni. 2016. "Peningkatan Perkembangan Kognitif Melalui Pembelajaran Sains Pemula Dengan Metode Proyek Di Taman Kanak-Kanak.” FKIP UNTAN, Pontianak.

Muslih, Muhammad. 2016. "Tren Pengembangan Ilmu Di Universitas Islam Negeri Maulana Malik Ibrahim Malang." Teosofi: Jurnal Tasawuf dan Pemikiran Islam 6(1): 220-47. 
Pujiono, Setyawan. 2008. "Desain Penelitian Tindakan Kelas Dan Teknik Pengembangan Kajian Pustaka." Workshop Action Research untuk Guru-guru di MAN 1 Yogyakarta.

Surur, Agus Miftakus. 2017a. "Formasi 4-1-5 Penakhluk Masalah (Studi Kasus: Penulisan Karya Tulis Ilmiah Proposal Skripsi STAIN Kediri 2017).” Prosiding Seminar Nasional PPKn III: 1-8.

_. 2017b. "Peningkatan Fluency Dan Elaboration Dengan Modified Free Inquiry." EDUDEENA 01(01): 21-29.

- 2019. "Standart Kinerja Pengajaran Dosen Pendidikan Matematik." Factor M 2(1).

Surur, Agus Miftakus, and Kharisma Nur Cholifah. 2018. "Good Governance Pada Kepengurusan Pondok Pesantren Putri Al-Amien." Al-Tadzkiyyah: Jurnal Pendidikan Islam 9(2): 261-74.

Surur, Agus Miftakus, Habib, and Pandi Rais. 2017. "The Application Program of the Preparation of the Syllabus and Learning Implementation Plan (RPP) 2013 Curriculum on Teachers Madrasah Ibtidaiyah." Proceeding International Conference on Islamic Education (ICIED) 2(Innovations, Approaches, Challenges, and THE Future): 246-253.

Surur, Agus Miftakus, and Aullia Rahmawati. 2018. “Organisasi Luar Sekolah Untuk Peningkatan Karakter (Studi Kasus Di IPNU IPPNU Ranting Ngreco Kota Kediri)." Ta'dib: Jurnal Pendidikan Islam 7(1): 347-56.

Susilo, M. Joko. 2006. Gaya Belajar Menjadikan Makin Pintar. Yogyakarta: Pinus.

Suyatno. 2009. Menjelajah Pembelajaran Inovatif. Sidoarjo: Masmedia Buana Pustaka.

Tim Pengembang Imu pendidikan FIP-UPI. 2009. Ilmu Dan Aplikasi Pendidikan. Bandung: IMTIMA.

Widodo, Wahyu. 2016. "Wujud Kenyamanan Belajar Siswa, Pembelajaran Menyenangkan, Dan Pembelajaran Bermakna Di Sekolah Dasar." Ar-Risalah $18(2)$.

Wijanarko, Yudi. 2017. "Model Pembelajaran Make A Match Untuk Pembelajaran IPA Yang Menyenangkan.” JURNAL TAMAN CENDEKIA 1(1).

Yensi, Nurul Astuti. 2012. "Penerapan Model Pembelajaran Kooperatif Tipe Examples Non Examples Dengan Menggunakan Alat Peraga Untuk Meningkatkan Hasil Belajar Siswa Di Kelas VIII SMP N 1 ARGAMAKMU.” Exata 10(1): 26-27. 
